\section{Effects of Auxin Treatments on in Vivo Propagation of Hippeastrum hybridum Hort. by Twin Scaling}

\author{
Antonio Fernando C. Tombolato, Cleide Azevedo, and Violeta Nagai \\ Instituto Agronômico, Caixa Postal 28, 13001 Campinas SP, Brazil
}

Additional index words. amaryllis, bulblet, rooting, 1-naphthaleneacetic acid, $1 H$-indole-3acetic acid, $1 H$-indole-3-butyric acid

Vegetative propagation of amaryllis is performed by twin scaling (Huang et al., 1990a, $1990 \mathrm{~b}$ ) or offsets (Okubo, 1993). A problem in twin scaling is the low occurrence of bulblets with vigorous well-developed roots. Successful acclimation in the field after the bulblets are transferred from controlled-temperature and humidity rooms requires high-quality bulblets with well-developed root systems.

Huang et al. (1990a) demonstrated the importance of two scales, instead of one, for twin scaling. They found that vascular connections occurred between the outer scale and protuberances initiated on the abaxial surface of the inner scale. They also observed that bulblet formation and leaf emergence were affected by the length or thickness of only the outer scale.

Studies on in vitro propagation have tested hormone treatment on amaryllis (e.g., Huang et al., 1990b; Yanagawa and Sakanishi, 1977, 1980), but growth regulators have not been tested for in vivo bulblet production. Therefore, we evaluated the effects of three auxins on root and bulblet development on twin scales of amaryllis.

On 24 July 1991, bulbs (6 to $8 \mathrm{~cm}$ in diameter) of 'Intokazi' and 'Red Lion' amaryllis were divided longitudinally into 16 wedges and then cut again so that each cutting consisted of two scales attached to a portion of basal plate (Rix, 1986). The twin scale outer and inner segments were kept separated to observe the effects, if any, of position. The twin scales were treated with $1000 \mathrm{ppm}$ methyl 1-(butylcarbamoyl) benzimidazol2-ylcarbamate - IUPAC (benomyl) for $5 \mathrm{~min}$. Then they were placed in wood trays filled with sterilized, moist vermiculite and maintained in darkness at 30C for 2 months.

Received for publication 15 Mar. 1993. Accepted for publication 26 Nov. 1993. The cost of publishing this paper was defrayed in part by the payment of page charges. Under postal regulations, this paper therefore must be hereby marked advertisement solely to indicate this fact.
On 25 Sept. 1991, the twin scales were removed from the vermiculite and rinsed with tap water. Then they were soaked in $1000 \mathrm{ppm}$ 1-naphthaleneacetic acid (NAA), $1 H$-indole3-acetic acid (IAA), $1 H$-indole-3-butyric acid (IBA ), or distilled water for $1 \mathrm{~min}$. Controls were treated with distilled water. After treatment, the twin scales were placed in 1 vermiculite : 1 peatmoss (v/v), wrapped with perforated plastic film, and arranged on wood trays. Trays were placed in darkness at $30 \mathrm{C}$ for 15 days. We counted the bulblets and roots for each twin scale and measured the length of the primary root.

We used a completely randomized design with four replications, and the following treatments: two types of twin scales, inner and outer; three auxin solutions and a control; and two cultivars. Each replication contained 15 twin scales. We performed an F test in an analysis of variance to determine the effect of cultivars and twin scale position. Auxin treatments were compared with Duncan's multiple range test.

Bulblet number. The control treatment had a mean of almost two bulblets per twin scale, whereas the auxin treatments had less than one bulblet per twin scale (Table 1). Because growers want to have only one bulblet per twin scale, the reduction caused by the auxins is desirable.

The mean number of bulblets in the outer twin scales was 1.4 compared to 0.6 in the inner twin scales. These results confirm the previous report of Huang et al. (1990a). Of the inner twin scales, $\approx 50 \%$ did not produce bulblets. cultivars of amaryllis. ${ }^{2}$

${ }^{2}$ Means for two cultivars are combined.

${ }^{\mathrm{y}}$ Mean of four replications of 15 twin scales.
Root. We observed no significant differences within the outer scales. Within the inner scales, however, NAA treatment produced the most roots (Table 1). Growers consider more than three or four roots per bulblet undesirable. With the NAA treatment, some scales produced more than 15 roots. For all treatments, 'Red Lion' produced 5.4 and 'Intokazi' 1.9 roots (difference significant at $P \leq 0.05$ ).

Cultivar and auxin treatment significantly influenced primary root length data. For 'Red Lion', NAA reduced mean primary root length by $\approx 50 \%$ in relation to the other treatments; for 'Intokazi', the reduction was less severe. For both cultivars, IBA induced the greatest root elongation, but the total length was not statistically different from that of the control (Table 1). Mean root length was $6.4 \mathrm{~cm}$ on the outer scales and $5.0 \mathrm{~cm}$ on the inner ones (difference significant at $P \leq 0.05$ ).

IBA, which improved root number of the inner scales without reducing root length, also reduced bulblet count to a mean of one per scale. This auxin treatment had the best effect when used at $1000 \mathrm{ppm}$.

\section{Literature Cited}

Huang, C.W., H. Okubo, and S. Uemoto. 1990a. Importance of two scales in propagating Hippeastrum hybridum by twin scaling. Scientia Hort. 42(1-2):141-149.

Huang, C.W., H. Okubo, and S. Uemoto. 1990b. Comparison of the bulblet formation from twin scales and single scales in Hippeastrum hybridum cultured in vitro. Scientia Hort. 42(1-2):151160.

Okubo, H. 1993. Hippeastrum (Amaryllis), p. 321334. In: A.A De Hertog and M. Le Nard (eds.). The physiology of flower bulbs. Elsevier Science Publishers, Amsterdam, The Netherlands.

Rix, M. 1983. Growing bulbs. Timber Press, Portland, Ore.

Yanagawa, T. and Y. Sakanishi. 1977. Regeneration of bulblets on Hippeastrum bulb segments excised from various parts of a parent bulb. J. Jpn. Soc. Hort. Sci. 46(2):250-260.

Yanagawa, T. and Y. Sakanishi. 1980. Studies on the regeneration of excised bulb tissues of various ornamentals with tunicate bulbs. I. Regenerative capacity of the segments from different parts of bulb scales. J. Jpn. Soc. Hort. Sci. 48(4):495-502.

Table 1. Effect of IBA, IAA, and NAA (1000 ppm) on number of bulblets produced by twin scaling two

\begin{tabular}{|c|c|c|c|c|c|}
\hline \multirow[b]{2}{*}{ Treatment } & \multirow{2}{*}{$\begin{array}{l}\text { No. bulblets/ } \\
\text { twin scale }\end{array}$} & \multicolumn{2}{|c|}{$\frac{\text { No. roots produced }^{y}}{\text { Twin scales }}$} & \multicolumn{2}{|c|}{$\begin{array}{l}\text { Primary root } \\
\text { length }(\mathrm{cm})^{\mathrm{y}}\end{array}$} \\
\hline & & Outer & Inner & Red Lion & Intokazi \\
\hline Control & $1.7 \mathrm{a}^{\mathrm{x}}$ & $3.1 \mathrm{a}$ & 1.8 & $7.7 \mathrm{a}$ & $4.1 \mathrm{ab}$ \\
\hline IBA & $0.9 \mathrm{~b}$ & $3.7 \mathrm{a}$ & $3.9 \mathrm{~b}$ & $8.8 \mathrm{a}$ & $5.4 \mathrm{a}$ \\
\hline IAA & $0.8 \mathrm{~b}$ & $3.5 \mathrm{a}$ & $2.4 \mathrm{c}$ & $8.1 \mathrm{a}$ & $4.0 \mathrm{~b}$ \\
\hline NAA & $0.6 \mathrm{~b}$ & $4.1 \mathrm{a}$ & $6.9 \mathrm{a}$ & $4.3 \mathrm{~b}$ & $3.3 \mathrm{~b}$ \\
\hline
\end{tabular}

${ }^{x}$ Mean separation between rows by Duncan's multiple range test at $P \leq 0.05$. 